\title{
Status of farm women of Assam as clientele of the agricultural extension services
}

\author{
POREE SAIKIA*, MANJU DUTTA DAS AND MANOSHI BARUAH DEKA \\ Department of Extension and Communication Management, College of Home Science, \\ Assam Agricultural University, JORHAT (ASSAM) INDIA \\ (Email : ppp.aau@gmail.com; manoshibdeka@gmail.com)
}

\begin{abstract}
A woman is the nucleus of the family, she share abundant responsibilities to perform wide spectrum of duties both at home and outside the home. She plays a significant role in agricultural development and allied fields. Despite their importance to agricultural production, agricultural development programmes are usually targeted at men. Women are generally by-passed in development efforts. A study was conducted in three agro-climatic zones of Assam to study the socio-economic status of farm women and to find out the status of farm women as clientele of the agricultural extension services. A multistage purposive cum random sampling design was followed. Altogether 1,200 farm women were included as sample of respondents. Data were collected with the help of structured interview schedule 52.60 per cent of farm women belonged to low socio-economic status. 55.17 per cent of farm women contributed labour independently in cleaning. On an average women spent 13-15 hours a day in farm and domestic activities. 41.67 per cent of farm women had attended training on fruits and vegetables preservation. Lack of awareness of the extension programme was the first most importance problems faced by farm women for attending extension training and ranked as I. Management of pest and diseases was the first most important training need areas of farm women and ranked as I. Lack of knowledge on plant protection was the first most important problems faced by farm women in cultivation of rice and ranked as I. It can be conclude that the status of farm as clientele of the agricultural extension service was not satisfactory.
\end{abstract}

KEY Words : Status, Farm women, Agricultural extension service

View Point Article : Saikia, Poree, Das, Manju Dutta and Deka, Manoshi Baruah (2017). Status of farm women of Assam as clientele of the agricultural extension services. Internat. J. Home Sci. Extn. \& Comm. Manage., 4 (1): 15-22. DOI : 10.15740/HAS/ IJHSECM/4.1/15-22.

Article History : Received : 16.10.2016; Revised : 19.11.2016; Accepted : 05.12.2016

\footnotetext{
* Author for correspondence (Email : poreesaikia@gmail.com)
} 